\title{
Film Pedagogy to Encourage Reflection of Juvenile Offenders Serving their Sentence in Juvenile Correctional Facilities
}

\author{
OKSANA B. PANOVA \\ Vologda Institute of Law and Economics of the Federal Penitentiary Service of \\ Russia (VIPE FSIN Russia), Vologda, Russian Federation \\ ORCID: https://orcid.org/0000-0002-6096-2581, e-mail: xenia-vipe@mail.ru
}

\begin{abstract}
Introduction. The article is aimed at characterizing reflection as a mechanism for social rehabilitation of juvenile offenders serving their sentence in correctional institutions; justifying the possibility of boosting this process by educational means; proving the expediency of using film pedagogy as a tool for the formation of self-reflection in juvenile convicts in correctional facilities. The purpose of this study is to identify the dynamics in the development of reflection of juvenile convicts under the influence of film pedagogy. Methods: theoretical analysis of the research problem, theoretical analysis of statistical data and normative documents, survey, experiment, methods of mathematical statistics, and an interpretative method. Results: after analyzing the statistical data reflecting trends in the penal enforcement policy in relation to juvenile convicts, the author forecasted the effectiveness of awareness-raising work stimulating the development of reflexivity in adolescents by means of film pedagogy. During theoretical description of a special film program, key ideas, pedagogical conditions and methodological solutions for its implementation were outlined; in further experimental study during the real pedagogical process, they were confirmed. The critical indicator of the proposed film program effectiveness was the level of reflexivity in juvenile convicts; positive dynamics in its development was determined with the help of the reflexivity diagnostic method developed by A.V. Karpov. The information obtained in the course of this study can serve as a basis for using the means of film pedagogy in solving a wide range of educational work with convicts in places of deprivation of liberty.

Ke y w o r d s: juvenile correction facility, juvenile offender, personality, pedagogical process, educational work, educational event, film pedagogy, reflection, reflexivity, selfknowledge, self-esteem, self-determination.
\end{abstract}

13.00.01 - General pedagogy, history of pedagogy and education.

For citation: Panova O.B. Film pedagogy to encourage reflection of juvenile offenders serving their sentence in juvenile correctional facilities. Penitentiary Science, 2021, vol. 15, no. 4(56), pp. 912-920. DOI 10.46741/2686-9764-2021-15-4-912-920.

\section{Introduction}

Child crime remains an unresolved socially significant problem, despite a certain decrease in its indicators in recent years. In the statistical reports of the Ministry of Internal Affairs of the Russian Federation, it is noted that in 2020, juvenile delinquency amounted to $3.9 \%$, that is, $11.5 \%$ lower compared to the previous year [15]. Official sources of the Federal Penitentiary Service of Russia record a significant reduction in the number of minors serving sentences in juvenile correction facilities (hereinafter re- 
ferred to as JCF) for the past 10 years: at the end of 2020, 948 people were held in 18 juvenile correction facilities, i.e., 4.3 times less than in 2010, when there were 4,053 inmates in 62 institutions. The vast majority of juvenile convicts, 934 pupils (98\%), serve their custodial for the first time [18].

The analysis of the information provided allows us to identify trends that are significant in terms of organizing a correctional process in juvenile correction facilities. First, the reduced number of such institutions and the decreased occupancy rate ensure full-fledged educational work with convicts, both in terms of material supply and sufficient meaningful support of pupils. Second, the JCF structure is dominated by persons without previous penitentiary experience. In our opinion, shared by a number of scientists, it is the basis for forecasting the possibility of social rehabilitation of adolescents, provided that high-quality, scientifically based educational work is ensured [1, pp. 27-29; 6, pp. $6-8 ; 4$, p. 32]. The idea that each subsequent conviction significantly reduces the possibility of overcoming the personal deformation of a convict is confirmed in the studies of leading domestic criminologists. Analyzing the works of Yu.M. Antonyan, V.G. Bovina, V.P. Golubeva, A.F. Zelinsky, Yu.N. Kudryakov, V.E. Eminova, etc., E.A. Antonyan notes that persons serving multiple sentences in places of deprivation of liberty are characterized by "criminal self-determination - person's involvement in a criminal environment, which inclines him/her to criminal activity, actively prevents him/her from returning to an honest life" [1, p. 29]. The stated above substantiates the importance of increasing the JCF employees' responsibility for the results of educational work and providing them with necessary scientific and methodological assistance.

Successful educational work with convicts also depends on actualizing psychological mechanisms that involve transformation of pedagogical influence into positive personal qualities of the educated. Reflection is one of such mechanisms; it is the psychological process, presupposing that a person studies himself/herself by comparing his/her thoughts and actions with socio-normative requirements of society. Reflection is not only cognitive, but, first of all, emotional and evaluative activity that requires the subject to master certain skills of self-knowledge, self-esteem and self-criticism.

The works of many scientists, including A.V. Brushlinskii, F.E. Vasilyuk, E.N. Emelyanov, A.V.
Karpov, G.P. Shchedrovitskii, etc., are devoted to the study of the phenomenon of reflection. The scientific foundations of A.V. Rossokhin are of particular relevance for our research. According to the researcher, reflection is "an active subjective process of generating meanings based on the unique ability of a person to realize the unconscious (reflection of the nonreflexive), that is internal work leading to qualitative changes in value-semantic formations, construction of new strategies and methods of internal dialogue, integration of personality into a new, more holistic state" [14, p. 24].

A.V. Karpov emphasizes that the content of reflection implies the need to consider its 3 key types, distinguished by the so-called "temporary" principle: situational (actual), retrospective and perspective reflection. Situational reflection provides direct self-control of a person's behavior in an actual situation; retrospective reflection manifests itself in the capability to assess events that have already happened; perspective reflection correlates with the function of looking into upcoming activities and behavior [7, pp. 45-57]. With this understanding, reflection helps a minor convict to consider negative consequences of the crime committed, determines the admission of guilt, actualizes remorse, and encourages him/her to leading life based on social norms.

Film pedagogy is one of the effective means of encouraging adolescents to reflect; it is a direction of art pedagogy devoted to the study of specifics of the educational impact of cinema and television on personal development of a person. The term "film pedagogy" is quite actively used in modern textbooks, scientific articles and the Internet. Laws, principles, forms and methods of human education through screen art is its subject. Summarizing conclusions of the scientists who have studied the influence of cinema on the formation of a child's personality (V.A.Razumnii, O.A. Baranov, I.S.Levshina, etc.), D.V. Bosov, Yu.N. Usov and others state that education with the help of cinema boosts the process of socialization. The communication method helps young people to acquire moral and civic experience through the world of social values, clarify their life positions and attitude to themselves and society [3, p. 3; 17, pp. 18-19].

We share the opinion of E.I. Zakharova and O.A.Karabanova, particularly: cinema has a metaphorical effect on viewers, as they feel comfortable to analyze and discuss the problem posed by the author. Whereas a "direct direc- 
tive approach in education provokes defensive reactions of a person, it does not let him/her come to realize a problem situation and elaborate it thoroughly" [5, p. 59]. The relevance of this provision in relation to children with mental and other personal disabilities is confirmed in the scientific works of D.V. Bosov, R.Yu. Dolya. The scientists claim that with the help of cinema the educator can "localize the foci of problematic functioning of the psyche" and "remove the outburst of destructive emotions of minors" [2, p. 144].

In relation to juvenile convicts, cinema acts as a special tool for life understanding for a number of reasons, which include closeness and social limitations of the educational system adopted at the correctional institution, convicts' negative social experience, their lack of opportunity to test themselves in various social roles, lack of positive examples in the immediate environment, etc. By watching movies, inmates gain the opportunity to expand their knowledge of life, master the "science of survival", comprehend the requirements posed by JCF employees, experience a variety of emotional states, compare themselves with film characters and put themselves in their place, evaluate their capabilities in terms of modeling their own behavior in similar situations. All these resources promote reflexive activity of young people significantly. The significance to involve correctional institutions inmates into reflexive activity with the help of cinema actualizes the identification and justification of pedagogical means designed to ensure successful correction.

\section{Methods}

In order to achieve the stated goal, a number of methods are used in the course of the research. When studying the relevance of the use of cinema in the correction of juvenile convicts, the theoretical and empirical methods were used: the statistical data reflecting characteristics of JCF inmates were analyzed; the penal enforcement legislation was examined in the aspect of identifying and generalizing existing requirements for film screenings in juvenile correctional centers; scientific literature on the problems of film pedagogy and reflection was scrutinized; the survey focused on the study of organizing a correctional process with the help of cinema was conducted among educators of the juvenile correctional center; the theoretical description of a special program based on the ideas of film pedagogy was conducted; the pedagogical experiment, including ascer- taining and forming stages, was implemented to evaluate this program effectiveness. The method of diagnosing the reflexivity development level, particularly the questionnaire, elaborated by A.V. Karpov, was used as a basic method to identify the direction of dynamics of the process under study at different stages of the pedagogical experiment. The significance of the data obtained was determined using mathematical statistics methods: the Wilcoxon signed-rank test was used to identify the direction and expression of changes before and after implementation of the special program. The application of the methods of generalization, comparison and interpretation was caused by the need to formulate general conclusions of the study.

\section{Analysis and discussion of the results}

The penal enforcement legislation regulating critical aspects of punishment execution defines the norms related to the use of cinema in educational work with juvenile convicts. The article of the RF Penal Enforcement Code (PEC) "Viewing movies and TV shows by persons sentenced to imprisonment, listening to radio broadcasts" sets the time for watching movies - at least once a week, TV shows - during off-duty hours, except for the time allotted by the daily routine for night rest. To meet the requirements of the Norms for creating a material and technical base for organizing educational work with convicts in correctional institutions, films are shown in a club or in a canteen club, accommodating all convicts in the juvenile correctional facility for them to watch the film simultaneously [10]. The article "Penalties applied to persons sentenced to imprisonment in juvenile correctional facilities" provides for deprivation of the right to watch movies for one month as a punishment (Article 136 of the RF PEC). Thus, the penal enforcement legislation, first of all, considers cinema as a means of implementing regime requirements.

The research in the practice of educational work with convicts in 14 juvenile correctional facilities, including the Bryansk JCF, Kolpino JCF, Arkhangelsk JCF, etc., allows us to describe the order in the organization of cinema screening. During the survey of 35 educators and social work specialists, it is revealed that the penalty in the form of deprivation of the right to watch movies for a month is rarely used in practice, as inmates, having right and the opportunity to watch movies on TV, do not consider it as punishment. Educational activities related to the use of cinema are more often referred to as 
a mass form of educational work, called "cinema screening". Feature films, as a rule, are approved by the correctional institution administration; relevant information is placed on special stands; demonstration of films is carried out under control of the administration; demonstration of films promoting incitement to national and religious hatred, cult of violence or cruelty, as well as containing scenes of a pornographic nature, training of special units, mountain training and parkour, the device and manufacture of explosives and narcotic substances is prohibited. The existing procedure is fully consistent with the Instructions on the organization of educational work with convicts in juvenile correctional facilities of the Federal Penitentiary Service [11].

During the survey conducted among JCF employees it was found out that patriotic films predominated in the content structure of film screenings (more than 60\%). Adventure and comedy films are the most popular among convicts; they make up about $15 \%$ of the structure of film screenings. As for plans of educational work with convicts, there is no trend that would indicate a systematic approach to the compilation of the film repertoire and the presence of a tradition of discussing the films viewed during specially organized educational events. There are exceptions that reflect the enthusiasm of individual educators, who discuss watched films with convicts. It can be stated that in most cases watching movies fulfils a spectacular and entertaining function associated with the need to organize leisure time for convicts.

Against the background of underestimating the role of cinema as an effective tool for positive personal reorientation of juvenile convicts, it should be particularly noted that the transformative educational potential of cinema art in the aspect of developing reflection in adolescents consists in the fact that during viewing and thinking about the film, they transfer what is happening on the screen to themselves, compare characters' behavior and the director' personal stance with their own ideas about life. In the situations where the storyline reflects circumstances similar to the conditions in which minors find themselves, the mechanism of dereflection works: a person acquires the ability to abstract him/herself when assessing what is happening. V. Frankl, often using this method in his practice, does this to encourage a person "to discover an adequate reason for himself/ herself" [17, p. 18]. Revealing the essence of dereflection, V. Frankl explains that the object of evaluation for a person is a certain stranger who finds himself/herself in a similar situation with this person. In the circumstances when a person distances himself/herself from physical essence, the process of evaluating "not himself/herself", but "the other", does not harm his/her psyche. At the same time, the similarity of circumstances encourages the projection of value judgments already "towards him/herself". Thus, dereflection awakens reflection.

Successful implementation of tasks related to the motivation of young people to reflect by means of cinema is determined by a number of pedagogical conditions, the most significant among which are:

- composition of a film repertoire, including such films that orient the viewer to a life choice in critical circumstances;

- organization of discussion of key issues aimed at socio-normative choice;

- consideration of social and psychological characteristics of juvenile convicts that hinder their perception of socio-normative attitudes. Such features include loss of socially useful connections; inadequate perception of social reality; oppositional attitude to the norms established by state institutions; divergence of moral norms, views, values with generally accepted norms, etc.;

- reliance on the positive potential of age characteristics of minors, such as sensitivity in the perception of social norms; a desire to search for the meaning of life; need for social and personal self-determination; a tendency to consider facts and events mainly in terms of morality; orientation to group interactive communication with peers [8, pp. 45-47].

Summarizing the listed conditions, we note that their implementation can be provided within the framework of the film program - a special program, the content of which consists of film screenings with subsequent discussion. In the development of such film programs, a special role is assigned to the selection of films and the preparation of scenarios for educational activities. According to E. Marsick, it requires "fineadjustment" of the pedagogical process and determination of its semantic boundaries" with regard to the specifics of an education object [19].

The effectiveness of the use of these pedagogical conditions is confirmed by results of the formative experiment (hereinafter referred to as the FE), in which 56 convicts serving sentences in the Bryansk JCF were involved. The participants were assigned to an experimen- 
tal group (hereinafter referred to as EG) and a control group (hereinafter referred to as CG). In each group, consisting of 28 people, there was the same ratio of convicts, boys aged 15-17, belonging to certain levels of reflexivity, a quantitative characteristic demonstrating the intensity of the ability to reflect.

The core of the FE was a film program that met the requirements listed above and included films of diverse genres:

- biographical films telling about the fate of famous people who, having criminal experience in their youth, managed to make a choice in favor of a socially normative life and achieved great success: the film "The Republic of SHKID" about the formation of writers G. Belykh and L. Panteleev and their friends; "One Hundred and First Kilometer" and "Hello, Capital" about life of the film director Leonid Moryagin, etc.;

- detective stories: "Your Rights?", "Police Sergeant", "American History", etc., telling about young people who reflect whether "to lead criminal or law-abiding life?" in the circumstances where they have committed many illegal acts under the influence of adult offenders, etc.;

- war films: "It was the Intelligence", "Little Sergeant", "Ivan's Childhood", "Mishka Accepts Battle", "Swine", etc. about heroism of teenagers, including children with a criminal past, during the Great Patriotic War;

- documentaries: "About Life", based on fragments of some kind of "confession" of real criminals serving a sentence of life imprisonment; "Man" and "Awareness of Life: Who Am I?" - about a person's self-cognition; "Teremok" ("Little House") - about child drug addiction and finding ways out of the corresponding lifestyle;

- a comedy film: "Seven Nannies", the storyline of which illustrates absurdity of the illegal actions of a teenager committed against people who care about him.

The special film program had invariant and variable blocks. The film screening was attended by all inmates, and the discussion of films took place only in the EG during specially organized educational events dedicated to the exchange of views on key issues. In whatever form these events were held, priority attention in their preparation was given to preliminary formulation of the questions focused on determining the participants' semantic position, so the discussion was always of a substantive nature and encouraged pupils to make a conscious socio-normative choice.

Educational activities within the framework of the film program under consideration were carried out in various forms, including spectator conferences, thematic conversation, discussion, debate, free exchange of opinions, etc. The spectator conferences were aimed at expanding juvenile convicts' world view; inmates themselves prepared speeches on the stated topic. The participants' performances contained information that was related to the watched film, but went beyond it. For example, during the audience conference "Fate is fate, but the choice is yours", dedicated to the film "The Republic of SHKID", young people received additional information about how the destinies of movie characters developed in real life; what was fictional in the film and what was authentic; how the film characters acted in the circumstances of life choice that the teachers provided them, etc.

The conversation presupposed a questionand-answer method of involving inmates in the discussion and analysis of certain on-screen events and giving assessments. Much attention was paid to the ability of the educator to formulate questions in such a way that they "forced" the juvenile offenders to accept a point of view correlated with basic life values. The best mode of conducting a conversation was considered the one, in which the inmates also asked questions to the interlocutors (educators, invited guests, members of the public, each other), thereby inviting them to clearly and openly present their position.

The audience discussion included a group discussion of key problems of the film in order to actualize positive self-determination of adolescents. The discussion topic was announced in advance; the inmates received necessary information in the process of preparation. During the discussion, everyone had the opportunity to express their point of view, which developed the ability to reason, prove, formulate problems, etc. Compared to the conversation, the discussion was more time-consuming; it provided an opportunity for a broader consideration of problems. A special role in the discussion was assigned to the moderators. They, as a rule, acting as unbiased coordinators, nevertheless, sought to direct a talk in a rational direction. Moderators were clearly aware of what goals they pursued and what results they wanted to achieve. The audience discussion suggested a dispute; it helped mobilize reflexive activity of the inmates when solving problems related to self-determination and resist erroneous ideas and concepts, acquire the ability to conduct polemics, defend their views and convince other people of them. 
In general, the educational activities under the described film program involved group discussion of the films for highlighting social norms declared in the film considered and forming the juvenile offenders' own attitude to them. Being an effective means of educational influence, such events contributed to the formation of moral value orientations of the participants, stimulated the development of awareness, generated the convicts' interest in various types of artistic and creative activity.

Any format of film discussion always presupposed "considering event-focused situations" [13, p.11]. This means that each discussed issue contains a situational dominant, which is "an actualized internal state of a person that determines what is significant in the content of the discussed event" [9]. During the discussion, the inmates are assisted in analyzing the event and determining what is primary and secondary. At the same time, it is very important to highlight that part of the event that provoke selfcognition among the offenders.

To illustrate one of the situational dominants recorded during the audience conferences, we can consider the inmates' need to be the same as all "normal" (non-convicted) people in the eyes of others, be able to resist criminal influence and start an "honest" life. So, when discussing the autobiographical film "One Hundred and First Kilometer" and its sequel "Hello, Capital", the inmates thought over a future life of the main character, who turned to crime because of romantic illusions. The offenders wanted the main character to "break" with criminal lifestyle and choose a socially approved path.

According to the film plot, a young man was going to participate in the robbery of a jewelry store. At the film end, he was standing at the train station waiting for the train, and the viewer did not know whether the young man would leave this city for Moscow forever to hide from the "crime boss" and start a new life, or he would stay and rob a store. During the discussion, the inmates were offered a task: "Imagine that a young man asks for your advice. What choice will you offer? What will he you do in Moscow, if he goes there? Will he have more opportunities for theft there? Should he continue the "craft of thieves", if he stays in his town?

After watching the film "Hello, Capital", a story about first significant professional achievements of the main character, broken with the "thieve environment", the audience was invited to discuss the questions: "What would you ask a famous film director Leonid Maryagin, a proto- type of the film character?", "What traits of your character are similar to those of the main character?", "At what point in his life would you like to be in his place?", etc.

Most juvenile convicts would like the main character to leave for Moscow, continue his studies there, and lead an honest lifestyle. Arguing for such an opinion, the convicts voiced a kind of protest against cruel "laws" of criminal life, under which yesterday's "friends" of the "crime boss" according to the plot of the film were subject to cynical reprisals for the slightest manifestation of their independence. The situations reflecting a true picture of relationships characteristic of the criminal environment are presented in the film quite figuratively and naturally; it was this circumstance that played a role in awakening the minors' emotions. The offenders had the opportunity to imagine themselves in the place of someone who was severely punished for "defection" [12, pp. 338-339].

To determine the degree of influence of the described film program on the development of reflection in juvenile convicts, we used a reflexivity diagnostic method [7]. As A.V. Karpov, the author of this method, notes, it is based on a theoretical construct that concretizes general interpretation of reflexivity, as well as some other features of this property. Reflexivity as a mental property reflecting the ability and inclination to reflexive activity is presented in the method as one of the sides of the mental reality that correlates with reflection in general. The other two components of this reality are reflection as a process and reflecting as a special mental state. These three modes are closely interrelated and mutually determine each other, forming a qualitative certainty at the level of their synthesis, denoted by the concept of "reflection" [7]. Thus, reflexivity is always the result of reflection, the intensity of which is determined by the degree of expression of reflecting at a particular moment. The more active the motivation for reflexive activity on the part of educators, the higher the level of reflexivity of young people.

In work we used a SPSS computer program to identify statistically significant differences and an Excel program to calculate average values of reflexivity. The Wilcoxon signed-rank test was applied to compare the indicators measured under two different conditions for the same sample of subjects ( $E G$ and $C G$ ) in order to determine the direction and expression of changes before and after the FE. The Wilcoxon signed-rank test helped clarify, whether 
the shift of indicators in the EG was more pronounced than in the CG.

The use of A.V. Karpov's reflexivity diagnostic method allowed to reveal the dynamics of reflexivity of pupils in the EG, mediated by their participation in the film program in a full-scale format. Figure 1 shows that after the FE the average value of reflection abilities expression in "raw scores" reached 117.1 , which, according to the method, corresponded to an average level; in CG it was 109.9 and referred to a low level. In addition, it was found that the EG participants were more inclined to perspective reflection than to retrospective.

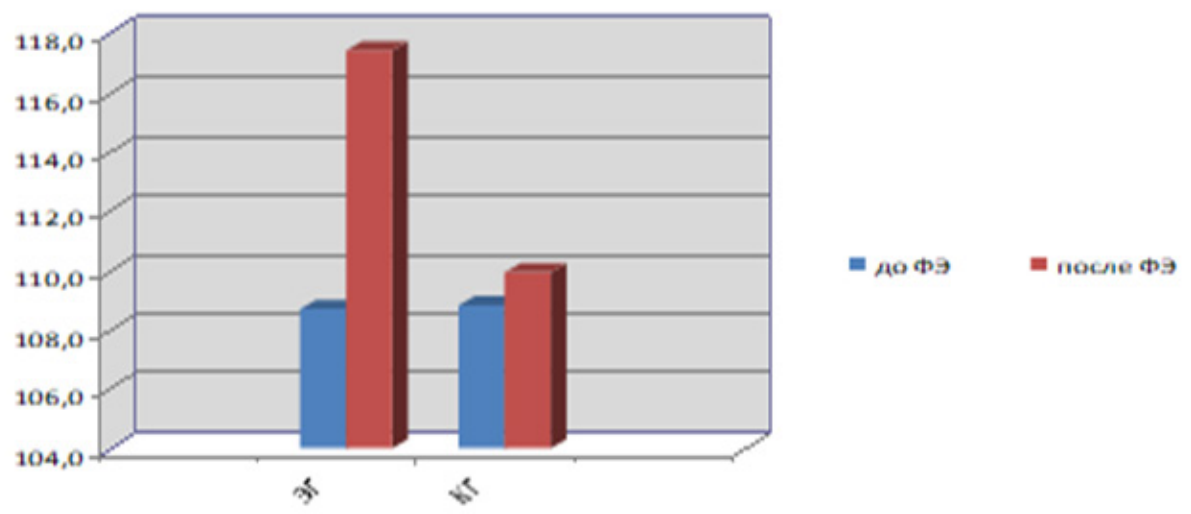

Figure 1. Average values of reflexivity of EG and CG participants before and after the FE (beforethe FE, afterthe FE)

Using the Wilcoxon signed-rank test, it was found that there were significant shifts in reflexivity indicators: the values in the CG were significantly lower than in the EG with the probability of significant differences $p \leq 0.05$. Consequently, the effectiveness of the implemented film program in the context of reflexive ability development can be considered mathematically proven.

Before the experiment both groups predominated by inmates with a low level of reflexive ability development. In the EG the number of minors with an average reflexivity level amounted to 10 people (35.7\%), with a low level - 18 people (64.3\%). In the CG 9 people (32.1\%) had an average reflexivity level and 19 (67.9\%) - low.
No offenders with a high reflexivity level were identified in any of the groups. There were no significant differences between the groups according to the studied indicator.

After the FE in the EG the share of participants characterized by an average reflexivity level increased significantly and reached $60.7 \%$ (17 people), with a corresponding reduction in persons with a low level (39.3\% or 11 people). None of the convicts had a high level in the EG, as before the FE. There were no significant changes in the CG: the proportion of people with an average level was 11 people (39.2\%), with a low level - 17 people (60.8\%); there were no convicts with a high level (Table 1).

Table 1. Indicators of the reflexivity development dynamics in the EG and KG before and after the formative experiment

\begin{tabular}{|l|c|c|c|c|c|c|}
\hline \multirow{2}{*}{$\begin{array}{c}\text { Diagnosis } \\
\text { stages }\end{array}$} & \multicolumn{3}{|c|}{$\begin{array}{c}\text { Experimental group } \\
\text { (n=28 people) }\end{array}$} & \multicolumn{3}{c|}{ Control group } \\
& (n=28 people) & Low level \\
\cline { 2 - 7 } & High level & Average level & Low level & High level & Average level & Low level \\
\hline before the FE & 0 & $10(35.7 \%)$ & $18(64.3 \%)$ & 0 & $9(32.1 \%)$ & $19(67.9 \%)$ \\
\hline after the FE & 0 & $17(60.7 \%)$ & $11(39.3 \%)$ & 0 & $11(39.2 \%)$ & $17(60.8 \%)$ \\
\hline
\end{tabular}

The analysis of statistical material under the described method for the reflexivity diagnosis showed the upward trend in the development EG participants' reflexivity. This proves the correctness of chosen forms and methods of educational work and the film program effectiveness in positive reorientation of juvenile convicts on the basis of self-cognition, selfanalysis, self-esteem and self-determination.

\section{Conclusion}

Stimulating reflection in juvenile convicts is an urgent task of the correctional process, since self-cognition plays an important role in positive reorientation of the individual. Film 
pedagogy is considered to be an effective tool for boosting reflection. It is a promising direction that focuses on the maximum use of cinema capacities in educational work based on scientifically substantiated ideas. The pedagogical conditions for encouraging correctional institution inmates to reflect are the following: careful selection of films focused on the idea of human self-determination within the framework of the integral program; involvement of offenders in the discussion of key issues related to the design of their own socially approved life; consideration of objective circumstances that hinder the perception of social norms by convicts, and neutralization of their influence; correlation of forms and methods of pedagogical communication with the age characteristics of minors.

The reflective activity of convicts is intensified not so much during the actual film screenings, as during specially organized educational events dedicated to the discussion of films. The forms of such events include spectator conferences, conversation, discussion, debate, etc. The differences between these forms affect, first of all, organizational aspects. The unifying principle of all events is the requirement that the discussion of films should be focused on eventbased situations that can actualize a vivid emotional response and promote participants' selfknowledge and awareness of their significance.

The research clearly differentiated concepts of "film screening" and "film pedagogy", highlighting the priority functions inherent in each of these phenomena. The main function of film screening is to occupy leisure time of pupils. The purpose of film pedagogy goes far beyond entertainment tasks; it consists in awakening the audience's need to understand themselves and realize their social mission in the past, present and future life.

The motivation of pupils to active reflection is provided by such opportunities of film pedagogy as expanding the worldview of young people, deepening their knowledge in the field of social norms of society, destroying negative stereotypes of behavior and myths of the criminal environment; expanding the range of acceptance by pupils of social norms and values that differ from the "thieves' common code of law", developing the ability to empathize other people.

The conducted research made it possible to identify the possibilities and problems of using cinema as an effective means of activating reflection in adolescents serving sentences in juvenile correctional facilities of the Federal Penitentiary Service of Russia. The provisions formulated in the article can become the subject of discussion in the professional community of JCF employees and act as a theoretical guideline for improving educational work with juvenile convicts in the direction of developing their qualities of subjective personality.

\section{REFERENCES}

1. Antonyan E.A. Lichnost' retsidivista: kriminologicheskoe i ugolovno-ispolnitel'noe issledovanie: avtoreferat dissertatsii na soiskanie uchenoi stepeni doktora yuridicheskikh nauk [The recidivist's personality: criminological and penal investigation: Doctor of Sciences (Law) dissertation abstract]. Moscow, 2014. $41 \mathrm{p}$.

2. Bosov D.V., Dolya R.Yu. Analysis of approaches, theories and concepts of film therapy in working with children with mental disabilities. Vestnik Maikopskogo gosudarstvennogo tekhnologicheskogo universiteta=Herald Maikop State Technological University, 2019, vol. 43, no. 4, pp. 143-153. (In Russ.).

3. Bosov D.V. Meinstrim-kinematograf kak faktor formirovaniya tsennostnykh orientatsii studencheskoi molodezhi: dissertatsiya na soiskanie uchenoi stepeni kandidata sotsiologicheskikh [Mainstream cinema as a factor in the formation of value orientations of students: Candidate of Sciences (Law) dissertation]. Sankt-Petersburg, 2017. 196 p.

4. Bystrova T.V., Pozdnyakov V.M. On increasing of hardiness in convicted for long-term imprisonment. Prikladnaya yuridicheskaya psikhologiya=The Applied Legal Psychology Scientific Journal, 2017, no. 1, pp. 30-36. (In Russ.).

5. Zakharova E.I., Karabanova O.A. A modern view of how to apply film therapy. Natsional'nyi psikhologicheskii zhurnal=National Psychological Journal, 2018, vol. 30, no. 2, pp. 57-65. (In Russ.).

6. Isaeva S.N. Sotsial'no-kul'turnye usloviya vospitaniya nravstvennykh kachestv vpervye osuzhdennykh v penitentsiarnykh uchrezhdeniyakh: avtoreferat dissertatsii na soiskanie uchenoi stepeni kandidata pedagogicheskikh nauk [Socio-cultural conditions for the education of moral qualities of first-time convicts in penitentiary institutions: Candidate of Sciences (Pedagogy) dissertation abstract]. Tambov, 2006. $22 \mathrm{p}$

7. Karpov A.V. Reflexivity as a mental property and the method of its diagnosis. Psikhologicheskii zhurnal=Psychological Journal, 2003, vol. 24, no. 5, pp. 45-57. (In Russ.).

8. Kon I.S. Sotsiologicheskaya psikhologiya [Sociological psychology]. Moscow: Moskovskii psikhologo-sotsial'nyi universitet. Voronezh: MODEK, 1999. 560 p.

9. Masharova T.V. Teoriya i praktika sotsial'nogo samoopredeleniya podrostka v uchebnoi deyatel'nosti: dissertatsiya na soiskanie uchenoi stepeni doktora pedagogicheskikh nauk [Theory and practice of social self-determination of a teenager in educational activities: Doctor of Sciences (Pedagogy) dissertation]. Yaroslavl, 1999. 392 p.

10. Normy sozdaniya material'no-tekhnicheskoi bazy dlya organizatsii vospitatel'noi raboty s osuzhdennymivispravitel'nykh uchrezhdeniyakh: Postanovleniem Pravitel'stva RF ot 2 avgusta $1997 \mathrm{~g}$. N 974 [Norms for the creation of a material and technical base for the organization of educational work with convicts in correctional institutions: RF Government Decree No. 974 of August 2, 1997]. Available at: https://base.garant.ru/1345278// (accessed September 14, 2021). 
11. Ob utverzhdenii Instruktsii ob organizatsii vospitatel'noi raboty s osuzhdennymi v vospitatel'nykh koloniyakh Federal'noi sluzhby ispolneniya nakazanii: Prikaz Minyusta Rossii ot 21.06.2005 N 91 (red. ot 21.07.2016) [On approval of the Instruction on the organization of educational work with convicts in juvenile correctional facilities of the Federal Penitentiary Service: Order of the RF Ministry of Justice Order No. 91 as of June 21, 2005 (amended July 21, 2016)]. Available at: https:// sudact.ru/law/prikaz-miniusta-rossii-ot-21062005-n-91/instruktsiia-ob-organizatsii-vospitatelnoi-raboty/) (accessed September 14, 2021)

12. Panova O.B. Pedagogicheskoe obespechenie pravovoi resotsializatsii nesovershennoletnikh osuzhdennykh $v$ vospitatel'noi kolonii: dissertatsiya na soiskanie uchenoi stepeni doktora pedagogicheskikh nauk [Pedagogical support of legal re-socialization of juvenile convicts in an educational colony: Doctor of Sciences (Pedagogy) dissertation]. Yaroslavl, 2013. $489 \mathrm{p}$.

13. Rozhkov M.I. The problem of the education purpose in modern pedagogics. Yaroslavskii pedagogicheskii vestnik=Yaroslavl Pedagogical Bulletin, 2010, vol. 2, no. 4, pp. 7-11. (In Russ.).

14. Rossokhin A. V. Refleksiya $i$ vnutrennii dialog $v$ izmenennykh sostoyaniyakh soznaniya: Intersoznanie $v$ psikhoanalize [Reflection and internal dialogue in altered states of consciousness: interconsciousness in psychoanalysis]. Moscow: Kogito-Tsentr, 2010. 304 p.

15. Sostoyanie prestupnosti v Rossii. Za yanvar'-dekabr' 2020 goda [State of crime in Russia. For January-December 2020]. Ministerstvo vnutrennikh del Rossiiskoi Federatsii, FKU "Glavnyi informatsionno-analiticheskii tsentr". Available at: https://xn--b1aew.xn--p1ai/reports/item/22678184/ (accessed September 14, 2021).

16. Usov Yu. N. Kinoobrazovanie kak sredstvo esteticheskogo vospitaniya i khudozhestvennogo razvitiya shkol'nikov: dissertatsiya na soiskanie uchenoi stepeni doktora pedagogicheskikh nauk [Film education as a means of aesthetic education and artistic development of schoolchildren: Doctor of Sciences (Pedagogy) dissertation abstract]. Moscow, 1989. 32 p.

17. Frankl V. Chelovek v poiskakh smysla: sbornik [Person in search of meaning: collection]. Moscow: Progress, 1990.366 p. 18. Characteristics of persons held in juvenile correctional facilities. FSIN Rossii [Federal Penitentiary Service of Russia]. Available at: https://fsin.gov.ru/structure/inspector/iao/statistika/Xarka\%20v\%20VK// (accessed September 14, 2021). 19. Marsick E. Film selection in a cinematherapy intervention with preadolescents experiencing parental divorce. Journal of Creativity in Mental Health, vol. 201, no. 5, pp. 374-388. Available at: https://www.researchgate.net/publication/233107694/ (accessed September 14, 2021).

\section{INFORMATION ABOUT THE AUTHOR}

OKSANA B. PANOVA - Doctor of Sciences (Pedagogy), professor of the Department of Legal Psychology and Pedagogy of the "Vologda Institute of Law and Economics of the Federal Penitentiary Service of Russia", Vologda, Russian Federation, ORCID: https://orcid.org/0000-0002-6096-2581, e-mail: xenia-vipe@mail.ru 